\title{
A WORK
}

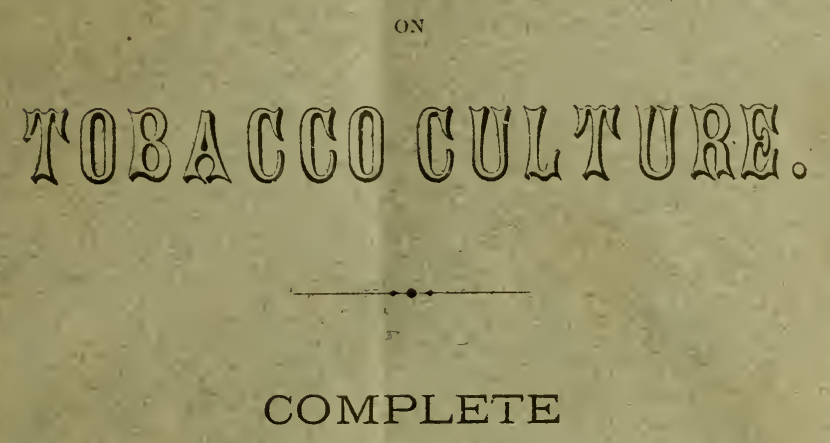

\section{FROII TIIE SEED TO TIE PICHRR.}

Being an Experience of Fifteen Years.

S. M. MILLER, Publisher, REFTON, LANCASTER COUNTY, PA.

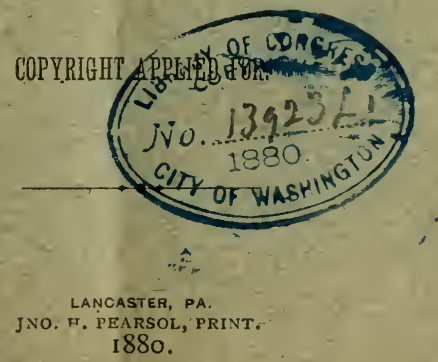
I880. 



\section{A WORK}

ON

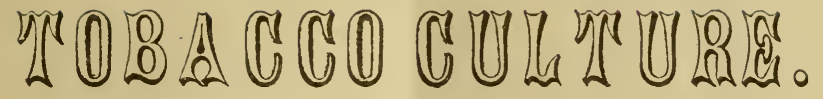

COMPLETE

\section{FRON TIE SBED TO TIIE PACKER.}

Being an Experience of Fifteen Years.

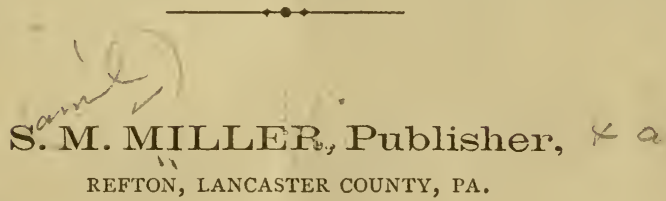

COPYRIGHT APPLIED FOR.

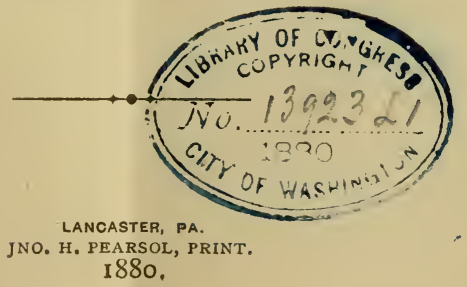

I 880 . 
In presenting this work to the public, the intention of the Author is not designed to rob the Farmer of his rights or lay out a new road to success; he feels assured he will receive the co-operation of every well-thinking Tobacco grower. Knowing full well it will come before the eyes of an envious few. It was written for a guide to those who can appreciate it for what it is worth; claiming it to be a guide to none of more experience than himself, but to those of less it is dedicated.

THE AUTHOR.

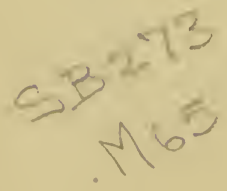




\section{A WORK OV TOBACCO CULTURE.}

In preparing this work on Tobacco Culture, the Author's aim has been to produce a work which should be recognized by the grower as striking a just balance between conflicting thenries, and as embodying what is best in the modern methods of 'Tobacco farming.

Naturally we might expect to find the condition of those engaged in the cultivation of Tobacco, both hopeful and prosperous. As a matter of fact, there is no other crop more languishing, or one that requires more care and attention, and lets the mind of the grower in a more unsettled state. A spirit of rivalry seems to exist in the minds of every one to have the most forward crop; next to have the longest and broadest leaves; and lastly to receive the most money. Yet if he has a forward crop, his mind is not at ease; perhaps the late maturing will be the best. If he can boast of some very large leaves; perhaps if his crop was more uniform in size, it would have been better in the end. And last, when he has received for his crop a fair price, his mind is not at rest lest his neighbor receives a better price. In view of a contrast so marked, we are at once and irresistably led to inquire into its cause, and to consider whether a remedy may not be found. To the Tobacco grower himself, who looks to this crop as in this section he is forced to do, as his chief if not only money crop, the solution of this problem is one of overshadowing importance. To settle at once this restlessness in the mind of the grower, and teach him to aim at something higher, so he may forget the rivalry of his neighbor, the early history of the plant; the derivation of its name, whether Nicot, Sir Walter Raleigh, or some other person was the first to bring it to the attention of the civilized world; whether it was at Jamestown, in Virginia, or at some other place in the path of our early settlers that it was discovered, it matters not; let it suffice that it was somewhere, and by some one. 
What are its elementary constituents, what its chemical and medicinal properties? These and all kindred questions pale into insignificance beside the one pertinent practical inquiry: How may the production of 'Tobacco be made more remunerative to the producer in this country? Turning aside then from the early history of this plant, now becomes but little more a luxury than a necessity of life; leaving it to others to trace its gradual but steady progress from a limited use in a crude condition by savage tribes to its present universal adoption in the various attractive forms in which it is to-day offered in every land and every clime. It will be our endeavor in this work to give you such instruction as will be for your lasting benefit. There has been great progress in the production of the 'Tobacco crop, but not in the way I would wish to see. Allow me to give you a few figures to show more fully what I refer to: In the year 1878 the entire crop in the State of Pennsylvania amounted to twenty-two million eight hundred thousand pounds $(22,800,000)$, raised on nineteen thousand acres (19,000), and brought two million two hundred thousand dollars $(\$ 2,200,000)$, while the crop of the year 1879 in Lancaster county alone brought over three million dollars $(\$ 3,000,000)$. That is certainly a great increase. What I would wish to see is, the number of acres decreased and the yield per acre increased. And let me say, brother farmer, until we aim at this we are laboring under a difficulty. Let us resolve in the next two years to plant at least one acre less, and raise one thousand pounds more of good Tobacco. Let us aim at quality instead of quantity. Some-yes, many Tobacco growers-have been so absorbed in their haste to get rich by growing this crop, that they have allowed their ambition to get the better of their sound judgment; and they think that to farm five (5) acres and 1000 pounds to the acre will pay as well as three (3) acres and (2000) pounds to the acre. They seem to consider the amount of acres is all that is necessary. With this statement respecting the erroneous ideas in the minds of some of our growers, I would earnestly invite their attention to some of the more salient and general features of this book.

In the treatment of Tobacco, both here and elsewhere, it has seemed very manifest to the author, that as a practical 
work, it is of the highest importance to lodge in the minds of the inexperienced grower, a definite knowledge that will stand by him when he needs aid. I doubt not the grower will gladly suffer the absence of the conventional jejune description of the Irishman, the Italian, the Esquimaux and the Chinese, when they find the space occupied with matter of solid importance. The preparation of this work has occupied much of the,author's time, and his most earnest efforts for the last fifteen years ; it is therefore not without anxiety that he awaits the verdict of those alone who are competent to pass judgment upon it. It affords him, however, a good hope of a favorable reception for the work, that it is the first of a careful study of the best methods as practiced by all successful Tobacco growers in Lancaster county.

\section{The Selecting and Management of the Seed Stalk.}

In the first place, it is highly necessary for every one growing Tobacco, to have his own seed and plenty of it. And not less important, is to have good seed. It is poor policy to depend upon your neighbor or the seed dealer to furnish you with seed; for upon the kind of seed you sow, and the variety of the Tobacco it happens to be, greatly depends your crop. If you depend upon some one else to furnish you with seed, you may get an inferior article. And perhaps your seed will not come up after having been sown, or at least not more than onethird of it, and the result is, you have your seed to pay for, your time and labor in preparing your bed, and sowing your seed lost, and you have your plants to buy in the end. In the next place, you may get a variety of plants that is far from what they should be, or what you would like to grow; and the greatest trouble is, you cannot discover the mistake until it is too late, and your time and labor is lost, and the result is a crop that will not meet your expectations. Instead of two thousand pounds to the acre, you have perhaps twelve hundred or less. It is a great mistake to think that seed is seed, and Tobacco is all alike. I would ask my farmer friends, why do you strive to get the choicest ears of corn, or that corn that has come the nearest to perfection; and in fact all other 
crops the farmer grows. His object is to secure the best seed. Then why should he depend upon his neighbor or the dealer to furnish him with seed for a crop of Tobacco, the very crop that he can lose the most or make the most money on. Now, my object is, to inform you how to get good seed, of a good variety; and that is, grow it yourself. I do not want to be impertinent in my language, but I am stating facts, for it is the only way left for you to be sure of a good crop. In the first place, plant as early as convenient quite a number of plants; say two hundred (200) on the richest piece of ground you have. You may say why, what do you want with two hundred (200) seed stalks. Just wait ; out of those stalks I want you to select those only that will make good seed; for it is certain that all stalks will not produce good seed, no more than each stalk of corn will produce equally as good or perfect an ear. Now, when you have your plants set early, in good rich soil, you have nothing more to do than to keep it clean as you would the rest of your Tobacco patch, until your stalks begin to shoot, when it is necessary to go over your patch and top all inferior stalks, leaving those only stand that have a strong, vigorous growth. The next important step to be taken is, when the stalk commence to bloom; this will have to be watched with great care. Do not allow any stalk to go to seed that has not got a queen pod, unless it stands very close to one or more that has; as a stalk that has not got a queen pod, is to a certain extent barren, and will not produce good seed. What I mean by a queen pod is this: The main pod that grows out from the fork, or right in the fork of the main stalk. The advantages of the queen pod is this: it contains the life germ; or to it depends the fruitfulness of the stalk. You may say then, why let any, if ever so close, stand for seed without this pod. I will answer: "The pollen from the queen pod of one stalk will, if close, impregnate the flower of the other stalk that has no queen pod, and make them both fruitful; but it is highly necessary that the stalk or stalks that are to derive fruitfulness from one stalk, they must all be in bloom at the same time, otherwise it is of no use. Now, a very important point is this: You perceive the bloom does not all appear at the same time. This also must be watched very carefully. 
Just as the bloom of the queen pod becomes dry, or falls off, all the bloom that may be on the stalk at the time or may come on after, must be sheared off. After this is done carefully, look over your seed stalk, and any pod that does not grow frum the fork of a branch or from where a branch grew out; or, in order to make it still plainer, any pod that may grow from the main stem as if it grew just out of the bark, cut it off, it is not good and will spoil your seed. If, when you have followed my advice, you have only from ten (I0) to twenty (20) pods to a stalk, do not be alarmed; it is all for the best. Follow this process for a few years, and you will not only surprise your neighbors, but you will be surprised yourself at the improvements you have made in your crop with so little labor. I can assure you it will not only be a pleasant surprise, but it will be a financial surprise, which is the more agreeable. Never rob your seed stalks of their leaves until after their bloom has all fallen off, as by stripping the leaves off too soon you may ruin your stalks. But after the bloom has fallen off, the leaves may be taken off. And let the stalk stand until the pods have all turned brown and dry, then cut the tops off, tie up in bunches and hang up in your garret so as to keep dry and get plenty of air, until they become perfectly dry, stalk and pod, when you can hull the seed and bottle it up for use. If you follow this advice you will have plenty of good seed for yourself that you can rely upon.

\section{The Selection of the Seed Bed.}

You should by all means select a southern slope, and should be protected from the cold north winds. If you have not got such a position given you by nature, you can at a trifling cost and with very little labor make just the kind of a place you wish. After selecting the most convenient place for your seed bed, dig into the ground eight (8) feet apart, posts of any kind and as many of them as you wish. You must be governed by the quantity of plants you wish to raise. After having your posts set, board it up close, about five (5) feet high. 'That will keep off the cold winds. South of this you can make as many beds as you see fit. Do not make your 
beds more than four (4) feet wide, with paths between them at least twenty (20) inches wide. Your beds, if of this size, will be more handy to weed and to pull the plants than if they are too wide. They should also be boarded up so as to be more convenient. It is very necessary to make all needful calculations in time so as not to be hurried too much when the time comes that you want to prepare your beds and make them ready to receive the seed - as you will doubtless find by following me to the end, that the Tobacco in all its different stages requires very careful management, and it will pay no one to hurry over any part of it.

\section{The Preparation of the Seed Bed.}

This I propose to do the previous fall, just before the ground freezes up. After you have yourprotection put in place as described, proceed to board up your beds; this you can do by driving stakes into the ground and nailing boards against them; then let the north side be, say one foot high, with the other side about four inches high; that will give the beds a good slope to the sun. Having your beds boarded up, the next in order is, secure plenty of good fine manure; that from the horse stable is the best ; put it on unsparingly, spade it in as deep as possible, and rake it as level as you can. After you have your beds thus dug, secure for every one hundred (Ioo) square feet, say two (2) bushels of saw dust, which can be obtained at any saw mill, two (2) bushels of chip dirt from your wood pile, and two (2) bushels of new dirt; that is, soil that has not been cultivated. This you can readily get from your fence corners, by digging off the sod and taking only the soil; run the whole through a riddle so as to remove all the coarse chips or stone that may be in it, mix thoroughly together, and spread evenly upon your bed. This quantity is sufficient for one hundred (Ioo) square feet ; fix each bed in this manner. After this is done cover your beds over with good manure from the horse stable, at least three (3) inches thick, which will prevent the escape of ammonia from the soil; and in fact will add to it by the rains falling upon the manure and soaking in during the winter. And in fact manure only acts upon 
vegetation after it has turned into a liquid state. Give yourself no more trouble about your beds until just before you are ready to sow your seed in the spring, then rake off your manure carefully; and with your garden rake, rake thoroughly your beds over as level and evenly as possible; let it lay for at least four (4) hours in the sun, so as to become perfectly dry upon the surface, which will be a guide to you to sow your seed by. Just previous to sowing, secure about six (6) quarts of hen manure, pulverize it, add to it one pint of common salt and mix well together. This quantity is for one hundred (Ioo) square feet; sow evenly over your bed, rake lightly; after this is done, your beds are ready to receive the seed.

\section{How to Sprout the Seed.}

Take a quantity of seed, say from one to five teaspoonfuls, have it inclosed in a cloth of any kind for convenience; now have a short piece of board, say one foot square, over this board spread two thicknesses of old woolen cloth; now soak your package of seed at least twelve hours in lukewarm water, then open your package, spread it upon the board, and cover with two more thicknesses of woolen cloth and place in a warm place of an even temperature; dip it again into warm water just before it becomes dry. It has to be watched very carefully so as not to become too dry, or the sprout will wilt and die. Just as soon as the seed bursts and the tiny sprouts appear evenly through your batch of seed, it is ready to sow. Very many people spoil their seed in sprouting it, by leaving it become too dry, or by keeping it too wet, or by smothering it, as light and air is very essential to the germination of all seeds. If when your seed is ready to sow and the weather will not allow you to sow it for some time, or until the seed becomes too much sprouted, you had better throw them away than sow them. You should, however, not allow yourself to be caught without seed on the way; so that in case your one lot should not do, you can fall back upon another supply. You should not sow your seed all at one time. If you wish to plant any quantity of Tobacco, you cannot, and in fact should not plant it all at one time. The same 
way you must make it with your seed sowing; sow some now, and in three or four days after sow again, and in a few days after sow another bed, so that you will not be at a loss when you come to plant.

\section{The Proper Time for Sowing Seed.}

Sprouted seed should be sown any time from the fifteenth of April to the fifth of May. Seed sown early in April, should by all means be covered; at any rate after night, so as to protect the tender tiny plant from the cold night air and the danger of frost. Some use glass, some bristles, some light muslin. The author prefers muslin, for it answers the same purpose and is far more convenient, and the cost is very trifling, as it can handily be removed in case you want to water or for any other reason. It is a mistaken idea that it takes as long to grow the plants as the Tobacco. From thirty-five to forty days is time enough to grow plants, if you sow seed properly sprouted and properly cared for.

\section{How to Sow the Seeds.}

The only safe way to sow sprouted seed, is to sow with water. Take your watering can almost full of lukewarm water, and into this place a heaped teaspoonful of the sprouted seed. If the surface of your bed is dry, as it should be, you can very readily, with a little care, sow your seed even, as you can see just where your water falls; and where the water falls the seed will fall too. Care must be taken to keep the seed well stirred up in the can, as it will settle to the bottom. This you can easily do by simply shaking the can, or by catching it by the carrying handle instead of the other one, this will cause the water in the spout to rush back into the can, thus stirring the seed up completely. Do this several times while sowing, and with care you will have the seed sown evenly over your beds. There is much more danger of you getting your plants too thick than too thin. The can full of water and teaspoonful of seed is sufficient for one hundred square feet, as you will find by experience before transplanting time. 


\section{Management of Plants.}

The most essential point in raising plants, is after the seed has been sown. Do not allow your beds to become dry, for if you allow them to become dry just one hour, the four first days after sowing your seed is ruined, as the sun will dry up the tender plants; and you must also guard against making the beds too wet, as nothing can grow in mud. Just keep your beds moist until your plants become a little stronger-then you must be governed by the weather; if it is very dry they will require more water, and as they increase in size they will need more water. You must keep all manner of weeds from among your plants. The weeds should be pulled when quite small, as they will crowd out your plants and smother them; and if left get too large you will spoil your plants by pulling them out, as the roots of the weeds are much larger than the roots of the plants. All that is necessary to the management of plants, is to keep them clear of weeds and give them the necessary amount of water. After your plants have well started and the weather becomes warm, remove the cover and let them harden and get used to the direct rays of the sun. There is more danger in keeping them housed up too much than by allowing them to run the chance of frost. Another very important point avoid if possible, watering with cold spring water; use if you can rain or creek water. You, however, may not all be so situated as to have either; in that case have a kettle full of boiling water ready, with that you can take the chill off a barrel, and that will answer the same purpose. I would, however, prefer rain water if possible, as it contains certain qualities that spring water has not; at any rate it seems to do the most good.

Now the time of day to water the plants is another point to consider. I prefer to water small plants, say until the first leaves are as large as a penny; to water in the morning between seven and nine o'clock. After the plants become larger and the weather warm, I would prefer to water in the evening or just before sunset. For this reason: while the plant is small and the nights cold and you water in the evening, the tender plant suffers from 
the cold, being wet; but as the plants get larger and stronger and the nights warmer, by watering in the evening the plant has more time to be benefited by the moisture than if they had been watered at nine o'clock a. m., under the direct rays of the sun.

\section{How to Prepare the Ground for Transplanting.}

Now this, perhaps, may meet with opposition. What I am about to say, and that is, sod ground should be manured well and ploughed in the fall, then run over it with a spike harrow, then a heavy roller, and let it lay until you want to prepare it for planting. Now I would advise as a general rule to use some active commercial fertilizer in connection with the barnyard manure. The best way to use commercial fertilizers I will describe before I close.

If you intend to plant on stock ground or old Tobacco land, the early spring is the time to plow. If you wish to use phosphate for Tobacco, if you have not become prejudiced against it, plow it down by all means; plow as early as possible so that it may not be too wet; if you plow too wet, you cannot get it in proper order. You cannot cultivate and pulverize. Tobacco land too much on the surface-just so that your ground is well settled ground T.hat ploughed in the fall should not be ploughed in the spring again, as your ground will not get settled by planting time, and Tobacco will not grow until the roots get down on solid ground, and your land will hold the moisture longer in using any kind of a phosphate as a top dressing. Strive to have it in the ground at least two weeks before planting time. In using phosphate, strive to get it down. I would here suggest: with your scorer replaced with large shovels instead of the ordinary ones, or with the plow, score out your ground; I would say in thin land, three feet and three and-a-half feet; that is, one row three feet and the next one three and-a-half feet; but if your land is strong, you should have the rows at least four feet and four and a half feet. The reason for this is, if your Tobacco gets large it will not crowd you out from worming and suckering; but by my method you will find you have room in every other one, and it is much better to let the sun shine upon the ground as much as 
possible; now score out as described, and as deep as you can, so as to get your fertilizer under your plant. After you have your fertilizer in the row, ridge it over and let it remain until you are ready to plant. The quantity of fertilizer to use you will have to be the judge yourself. I might suggest, but I know nothing about your land-and it is sure as every one knows, poor land requires more than rich. One thing is certain, land cannot be too rich, yet you can put ioo much of the fertilizer near your Tobacco plant. If your land is thin, you should by all means plow down at least eight hundred to a thousand pounds to the acre, and then come after with an active top dressing. The great trouble with most people using commercial fertilizers and receiving little or no benefit from them is easily explained. The secret is simply this: they do not use enough of it; they sprinkle three or four hundred broadcast to the acre without any manure, and expect a good crop; now that is useless. You have received little or no benefit by using so small a quantity. Just suppose for a moment, you would spend the price of four hundred of the most expensive phosphates made. In barnyard manure spread it on an acre, and you will see little or no benefit either. You may say yes, but when I make the manure it costs me nothing. But hold on, what would it bring if you offered it for sale, and count the amount used at that price, and you will readily perceive you could put a ton to the acre at a less cost.

The next trouble met with by some people is, they gef it too near the surface, and the good qualities of it escape; or else they stick the plant right into it, and consequently the plant is destroyed. That is the reason why I advise you to score out your ground deep, and put your fertilizer down and ridge it over; it will come up, and the roots of the plants will find it just when they need it.

I deem it necessary to inform my patrons in regard to what kind of commercial fertilizer to use, as there are a large variety in the market and many of them very inferior. I have used many kinds of Phosphates for Tobacco, and given them a fair and impartial trial. I can safely say that the High Grade Ammoniated Phosphate, manufactured at Reading, Pa., by D. D. Hess \& Son, has given 
the best results, as it is very active, and that is what the Tobacco crop needs. It has been very extensively used throughout lancaster county the present season with the most happy results, both on limestone and barren soil. Many farmers who have heretofore cried down the use of Phosphates, have been induced to try the High Grade, made by D. D. Hess \& Son, and are to-day the loudest in its praise. It has given universal satisfaction, having been used by some of our most practical and successful growers, and to-day stands high in the estimation of all who have given it a trial. Those wishing to use Phosphate can do no better than to procure the High Grade, as it is manufactured on purely scientific principles, and not made up of two-thirds sand or refuse, that is of no material benefit to the soil. The manufacturers of this Phosphate make none but a first class article, and which can be fully relied on. The firm are of undoubted character; and I am safe in saying that you are perfectly safe in relying upon it for a good crop of Tobacco on any kind of soil, whether used in connection with barnyard manure or alone. I feel as safe in recommending this fertilizer to you as I do in giving you my mode of farming and handling Tobacco.

\section{The Time for Planting.}

The preferred time for planting is, say from June ist to June 25 th. However, some no doubt have raised good crops that have planted earlier, and perhaps good crops have been grown planted much later, but either is a risk and not to be advised. Just for example to those who have not had experience in Tobacco culture, I will take the corn crop to prove my theory. Have you not often been disappointed by planting corn too early; when the ground was cold and the cold rains came, and your corn did not come up as you thought it should, or turned yellow after it was up, and appeared stunted in its growth. On the other hand, have you not seen the same crop that had been planted too late and was killed in a green state by early frosts. Bring this to your mind and you have the Tobacco crop under the same circumstances; and it is not at all necessary by sowing your seed by my directions and preparing your ground in time you are ready to 
plant by the first mentioned date and if you commence at that time and finish by my last mentioned date, you can rest assured from danger of cold rains in the early part, and frost will not hurt your latest. It is not advisable for any one farming three or four acres of Tobacco to plant it all early, nor all late, according to my dates; twenty five days make quite a difference on the Tobacco crop. If you plant all early, you may get in a drought in the early part of the season; and by planting all late you may meet with the same results, but by having part of your crop early and part later you are not likely to have a total crop failure. You have also more time to handle it at harvest time, or at least are not hurried so much. No part of this work should be done in too great haste.

\section{How to Plant Tobacco.}

Now, kind reader, you have your Tobacco land well manured, well cultivated and prepared for planting; and if you have taken my advice with your plants, you have at the first of June-and that is time enough-plenty of good, healthy and vigorous plants ready for transplanting. Now how to set out the plants properly is the next question in the mind of the inexperienced grower. This I propose to tell you here. It is a mistaken idea that you must wait until it rains before you can plant your Tobacco; in fact quite the reverse is the case. If it rains heavy you should by all means. wait a day or two after before you plant, as in the mud is no place to plant Tobacco. I would not allow any one to plant for me immediately after a rain, if they were to do it for nothing and find the plants; in fact, in dry ground is the place to plant Tobacco. Planting in wet ground has blasted the hopes of many of our old experienced growers the present season, and to-day they cannot tell you what is the reason their Tobacco does no good. They say, my land is certainly good, for I have put on so many loads of manure, and so much phosphate in the rows, and that piece of land was good before. I had good large plants, and I have hoed it two or three times, and I have went over it three times with the harrow, and yet it does no good. They tell you all this, but they have forgotten one thing yet. They have 
neglected to tell you they set it out in the mud. That is the great cause of so much unevenness in Tobacco patches. After a heavy rain the farmer will start out with his plants and set perhaps two or three thousand plants; but he only gets perhaps one-third of his patch set to-day, and the balance he does not get planted before the second or third day after, and the mud has then dried up and the ground is in good order for planting and he sets out the balance of his patch, and it grows right off, and yet he will ascribe it to every cause but the right one. Now when the time of year is at hand to plant, and you have plants ready, do not wait for rain, but go to work and plant. Now I propose this: Take your marker, which is made in this manner; take two tobacco lathes, or pieces two and a half feet long, place them in the position of a half open compass, nail them together at the upper end and nail a cross-piece half way down, so as to keep them stationary; care must be taken to have them the right distance apart. If your land is thin or ordinary land, twenty-four inches apart would be right, but if your land is very strong, you had better have it twenty-eight inches at the points; now start at the end of your row and walk it right along on top of the row by whirling it around in your hand; right behind the spacer come after with a hoe, and hoe out a spot almost on a level with the surrounding surface, then with a stamper made by taking a block or piece of plank about five inches wide by nine inches long, with a hole bored in the center, and a handle put in about four feet in length; come after, stamp level and solid a place for your plant where it was hoed out. But do not under any circumstances set your plants in the mud, that is when the ground is wet enough to stick to your fingers. If you plant in wet ground you cannot help but plant too tight; the ground is pressed around the plants, and when it dries off you have formed a clod around the roots of your plant, so that they cannot possibly work through, and the consequence is, your plant stands still just as you set it in, and in fact dies outright from that cause. 'The plant is very tender and the roots small, and you have stuck them fast in the clod so they cannot possibly grow. You might as well expect your 
Tobacco plant to grow through a brick as the clod you have formed around it.

If you plant after a rain, and in a day or two it rains another shower, so as it forms no clod, your Tobaceo is all right, and it will grow; but when we plant in the mud we do not know whether nature will help us out or not, so we must guard against it; and the only way we have to do is, to plant in the dry ground; and you cannot plant too tight nor form no clod, all the danger is set aside, and you can earn ten dollars a day hauling water to plant Tobacco with.

You perhaps may not agree with me here, but I think I can prove this with figures to your satisfaction. Now if you set your plants in the mud or wet ground, and we get a dry spell of weather, your Tobacco cannot and will not grow, and you would be well off if you went over and hoed it all out and replanted it; if you work away at it sticking in the clod, your plants are lost, your labor is lost, and instead of getting a crop of from sixteen to two thousand pounds from the acre of a good quality, worth say twenty and five, you get a crop of from eight hundred to one thousand pounds from the acre of an inferior article, worth perhaps twelve and three, and it is all you can get, and you will perceive you have a difference of at least one hundred and seventy-five dollars, and I am sure it would not take you seventeen and a half days to haul water enough to plant one acre of Tobacco, and certainly you cannot make better wages this side of being a United States Senator. I have proven my assertion by figures, and they cannot lie; you can have that fact verified this season in hundreds of instances throughout this county. Now I do not wish to be understood that you dare not plant in damp ground; if you can do so, and if it rains, it is all right; and if it don't rain you are none the worse by planting in damp ground; you can sometimes save watering, but we cannot at all times get the ground in that condition; then do not wait, but plant in dry ground, and water; and if the sun is hot you must cover your plants. Now this is my method of planting, watering and covering. First, when you go to your plant bed to pull your plants, set apart one end of your plant bed about four 
feet square, and do not disturb any of the plants on it, but from the rest of the bed or beds pull your plants, all of a uniform size, or as near as possible. Commence in the middle of your patch to plant if you possibly can, as those first planted will likely be ready first to cut, and you have a road through the middle of your patch. For convenience, now proceed with a gardener's trowel, or one made from hard wood similar in shape, sink it down to the required depth in the spot prepared on the row, press your trowel to one side, take your plant with the other hand, let the roots drop down straight in their natural position, then draw out your trowel, and if the ground is dry the hole will fall shut or nearly so. You can bring some dirt up if necessary and thus proceed on with your planting, and you will find it is just as easy to plant in dry ground as in wet. Now it is necessary for you to water the plant after setting, as soon as you can, and that will set your plants. If the weather is clear and warm it will be necessary for you to cover your plants or the sun will kill them before they can take root. "This I propose to do in this manner : cover with paper; cut your paper into pieces about five inches wide by nine inches long, place the one end on the ground and place a little dirt upon it; bow it up in the middle so as to form an arch with the other end on the ground with dirt upon it, so as to keep it in that position and prevent it from blowing off. Care must be taken in making this arch so as to have the ends that are on the ground north and south.

- No doubt some one of my readers may say, why not set it east and west. Simply to prevent the noonday sun from striking the plant too much; in placing the cover in arch-shape we allow the plant plenty of light and air, so essential to plant life. Do not, under any circumstances, when planting, plant a large plant or two or three of them and then a small one; but plant plants of a uniform size. Your patch has then all the same chance; but you may say suppose some of the plants do not grow that we have set. Well, I have taken care of that-on the second or third day after, go over your patch to see if there is any missing from some cause. Now go back to your plant 
bed and you find a bed four feet square of plants larger than those transplanted, as they have been growing the two or three last days, while those set out have not commenced. Now you have large plants to plant after; do this as carefully as you did the rest and in the same manner, and at the end of a week you cannot tell where the re-plants are-they are alike. That is the great secret of keeping a patch even; by doing this carefully you will have a patch of uniform size, or nearly so, and it will stay so; but if you set large plants, in and alongside, you set a small sickly one all over your patch, and rob your plant bed, so your re-plants must be small plants, not fully recovered of being disturbed by pulling out the rest, what can you expect? The large healthy plant has always the advantage of the smaller one. There are, however, many causes for a Tobacco patch getting uneven without you starting it so. After you have done your best you will find some small stalks, which cannot be avoided in large patches; but by planting in dry ground and watering with a pint of water to each stalk and covering, and thereby avoiding the dangers I have described, you cannot help growing a good crop and a paying crop of Tobacco.

I have often heard it said, what makes that difference in your patch of Tobacco? and have heard many reasons given, but seldom the right one. The author of this work once planted five rows of Tobacco to prove this theory to his neighbors; five rows were planted in the morning after a heavy rain, the day proved a fine one, with sun shining all day, and in the evening he planted three more rows alongside of the five rows planted in the morning, and he had every one that saw it wondering what made the great difference. He harvested double the quantity off the last three rows as off the first five. Was not that plain proof? Yet that was not all the gain he had in the number of pounds; but the difference in price was as fourteen is to twenty, which is easily counted. By this time I hope you have your plants properly set and in a growing condition. Next comes the

\section{Cultirating the Tobacco.}

This must not be neglected, for I am safe in saying you 
cannot do too much at it. As soon as possible after you have your plants all set, I would advise you to get in with the harrow; for during the planting, watering and covering you get the middles pretty well tramped, and it is very necessary you should loosen it up. You cannot cultivate too soon after planting, either with the harrow or the hoe. Your patch should be harrowed after every rain or at least every ten days. Do this as long as you can pass through it without breaking the leaves. In regard to hoeing there are different opinions. Some hoe the dirt away from the stock, while others hoe to it. Now I have advised you to plant almost on a level with the surface between the rows; and by cultivating and hoeing I propose to have the patch level or nearly so. By hoeing the ridges down you readily destroy the weeds and grass, and leaves your patch in good condition; but the second and third hoeing, by all means hoe fresh dirt to the stock, thereby you keep the roots covered deeper, and they do not dry out so soon; however, do not hill up high so as to draw the water off, merely loosen the soil around the stalks, so as to readily receive the rain as it falls. Do not when harrowing merely skim over the surface, but harrow it deep; tear up the ground so it is loose for the feeders to get through; after that phosphate. I advised you to put in the ground and not on it. Harrow deep and often, hoe wèll and you will not only be pleased of the result but be paid well for your labor.

\section{The Tobacco Worm.}

Long perhaps before you are done cultivating the 'Tobacco you will discover the crop has an enemy, and a bad one too in the green Tobacco worm, which destroys the crop very much if not headed off. For the benefit of the inexperienced Tobacco grower, let me make it plain where this worm comes from, as it is evident it must in some stage of its existence have a different and a faster mode of traveling than it has when you find it destroying yo'ir Tobacco. That is so; the green worm you find was made by the Sphinx laying its eggs on the Tobacco, and there it hatches. When the worm has come to maturity it leaves the Tobacco and buries itself in the earth. In a 
certain time it is transformed into a worm of a dark brown color, not at all resembling the green worm. From that it changes and becomes a flying insect, resembling the humming bird. After it has laid its batch of eggs it dies, and so you see we can always look for two showers of worms in a season. They are a great enemy to the Tobacco farmer as they will entirely destroy the crop if left alone, and they increase so fast it requires considerable labor to hunt and destroy them. Various ways have been devised to prevent them. Some growers plant the Jamestown or Jimson weed in close proximity to the patch; then by poisoning the flower, kill the Sphinx or moth. Others employ lighted torches over a pan of tar, which proves a certain trap. Some try one plan and some another. My advice is, try any plan, try them all, then resort to hand picking, the surest of them all, rather than have your crop eaten to shreds and the labor of more than half the year brought to naught in a few day by a single glut of worms.

\section{The Process of Topping.}

Topping the Tobacco is an operation requiring considerable skill and judgment, and not easily described; but by all means allow me to say to you, do this part of the work yourself instead of trusting it to others. That as many plants as possible may ripen at the same time, a desire not to be undervalued, in aiming as all should at a uniform crop. Wait until a large number of plants begin to button or show the seed before commencing to top. Going about through the patch topping a plant here and there, because it has shown the seed-bud before its fellows, is productive of more injury than good. No inflexible rule can be given for the number of leaves that should be left on a stalk, all depends upon the variety of Tobacco, the strength of the soil, the promise of the particular plant, the probable season, and the time it has for ripening. My advice is, to always top low; rather have two leaves too little than two too many to a stalk. I would suggest from eight to twelve good leaves; but in no case exceed that number. Twelve good leaves and three for ground leaves is quite enough for any plant on 
any soil. It is much better to have large leaves than long stalks, as we care nothing about the stalk. There is no money made growing great long stalks and short leaves, but vice versa.

\section{Suckering the Tobacco.}

This will next attract the attention of the grower, and must be promptly attended to; that with worming will constitute a single operation. You need not, however, give yourself any trouble until the first three suckers ap pear the length of your finger, then they should be broken off. They will appear first at the top or where the bud stem was broken off. They will next appear at the next leaves, and so on down until they get to the lower leayes, which determines the time to cut the stalk, for when the suckers are from four to six inches long at the ground, you can safely cut your crop. You can also see quite a change in the color and feel a difference in the body; you will find the leaves will thicken up and become brittle, and you will also find by following carefully the instructions so far given, very little trouble in determining when you can with safety cut your crop. Care must, however, be taken not to cut too green, as by having one stalk very ripe and another only partly ripe, your Tobacco will not cure of a uniform color, which is very essential. After you have taken all the pains you can with the crop, in setting plants of a uniform size, replanting with good plants, careful cultivation, you will no doubt find some of your Tobacco will take the lead in growth, consequently will mature some days in advance of others, so you will have to be careful when you come to cutting, so that your stalks are all ripe, otherwise you will have some trouble when your Tobacco cures. We now come to consider the last operation in the field. Cutting the crop in this as in topping, a man of judgment and fidelity is needed. You should by all means be there yourself. An inexperienced hand, or one without jud gment, and particularly one who is indifferent to the interests of his employer, will slash away right and left, not knowing and not caring whether the Tobacco he cut be ripe or green, doing more damage in a short time than his whole year's wages would 
compensatefor. Therefore be on hand yourself and do not delegate the duty to any less interested party, so that a crop managed well-it may be so far from the initial plant bed-shall not be spoiled in the closing work by an incompetent or unfaithful cutter. Be there, too, to see in this important hour that injury from sunburn be warded off the stalks that have been cut. The neglect of this precaution has played havoc with many a good crop when it was ready for sale. The vigilance of the grower is constantly needed to guard against losses or mismanagement. As the Tobacco crop is something that counts fast on one side or other of the ledger, you cannot afford to raise a poor crop of inferior Tobacco, nor neglect the proper handling of a good one; they will both count poor and on the wrong side.

\section{How to Cut the Tobacco.}

I have endeavored, kind reader, to guide you on from step to step in the management of the crop, when it is to be hoped you will have a magnificent crop of Tobacco fit for cutting. Now you have a very particular work to perform; your money is all made when your crop is done growing, but you have not got it yet, and the amount you may get greatly depends upon how you handle it. You should never allow this to be done by careless hands. I would suggest to have two trussels at least sixteen feet long-twenty would be better-made of scantling. or even an inch board six or eight inches wide with legs nailed on about five and-a-half feet high to set in the field, to be moved around as you wish. Next you want a spudding buck, which is made in this manner: Take a piece of scantling three by four, or just the size you may have it, about six feet long at the one end or about ten inches from the end; we propose to fasten two legs, so as when the other end rests on the ground the end on legs will be three and a-half feet from the ground; now with a chisel cut a notch to fit your lath about four inches deep, nail a piece of board over it to form a mortice that a lath will go in, not too tight; now you are ready for the field, except some instrument to cut with. I would recommend a common hatchet or small saw made for that purpose; 
you also need a wagon fixed for the purpose of hauling your Tobacco to the shed, which I will describe on another page of this book. Now in cutting you take hold of the stalk about the middle, incline it slightly to one side and cut it not down but off, and take off all suckers and dry leaves that may be on the stalks, then lay it down carefully so as not to break any of the leaves. Proceed thus to cut off your entire crop, not, however, at one time; if it should be all ripe, you must guard against it getting sunburnt; when the weather is very warm in the early part of the season, I would advise not to cut any Tobacco before 4 o'clock p. m., as by that time the heat of the sun is not so great; however, in ordinary weather, or with the thermometer at seventy, you need not fear, but for the sake of convenience say cut two hundred stalks, then commence to string up your Tobacco; have, if possible, some one to help you, take hold of a stalk at the butt, one in each hand, pass it to the spudder who will string it up and place it upon the wagon or the long trussels I spoke about, placed near at hand, but in no case lay it down; proceed in the same way until your wagon is loaded; if you have help enough send that load to the shed or barn and cut down another lot; if your help is light hang your loose scaffold full, rather than allow it to lay on the ground while you take one load to the barn. There is, however, one very important point right here for you to bear in mind: Never cut Tobacco right after a rain, but let it stand at least six hours in the sun so as to again draw its gum, as when it is cut wet and the Tobacco cured, it has no more life than a dry chestnut leaf, and is poor stuff. This the grower must bear in mind, as by neglecting this warning you may ruin part of your crop. Another very dangerous plan is practised by many of our bustling farmers and that is this: They will string up two or three loads of Tobacco more in the evening than they can get to the shed, and they leave it hang on the scaffold in the field until next morning; there may be a very heavy dew and the farmer will say to the help, "it is too wet to sucker and worm, go hitch up and we will go out and bring that Tobacco in that is hanging on the scaffolds;" and in it comes, all wet, and is hung in the shed; and, if 
the leaves have not all fell off before, you will take it out at stripping time rotten, and it is a total loss. It has often been the case with farmers that have grown the crop for years, but the careful farmer that has been gaining knowledge at the losses of his neighbor endeavors to steer clear of all these troubles, for it is the minor points in the culture of Tobacco that makes one grower more of a success than another. And to those who would become successful Tobacco growers, let me add it should have the personal superintendence of the owner.

\section{How to Hang the Crop in the Shed.}

The next question in the mind of the inexperienced grower is, "how shall I hang my Tobacco so as not to damage?" for upon this depends the prices. It is well known that damaged goods will not sell, and the crop may have been brought along successfully even to this point and lack one thing yet, if it be not now properly manipulated. Go into the shed yourself and see to it. You will readily see I have advised you to haul it right from the field in a green state, without having it wilted together and without having it laid down on piles so as paste together. By hanging it into the shed or barn green from the field you cannot hang it too close together without breaking some of the ribs; and if hung up in the shed green and it wilts there, you need not fear it will be too close, but your stalks will hang there loose, not all pasted together like two cakes of wax, the air almost excluded from it except the outside leaves, and when it is cured it will resemble a bunch of feathers. It is a mistaken idea that Tobacco is burnt in the shed by being hung too close; not at all. I will endeavor to prove to the most skeptical, beyond a doubt, that it is not burnt at all; for nothing can burn without being hot, and if you take pains enough to examine your tobacco at that time, or when it is spoiling, you will find it cool. I am not prepared to say whether those who say their tobacco is or was pole burnt, or mow burnt, really thinks it is burnt or whether they only make use of the word for the sake of convenience. But I am sure it is used out of place. I cannot, perhaps, name it properly myself, but I would 
say it is smothered, or in other words, it rots for want of air of the right temperature. I will endeavor to give you the cause of tobacco rotting in the shed by asking you the following question: "Have you ever noticed a pitcher of cold water brought into a warm room? did not you notice the pitcher sweating, as it were, on the outside?" If you have not, just try it to convince yourself of the truth of what I may say. It will form drops of water on the outside. To more fully convince yourself, place another pitcher alongside full of warm water, of at least the same temperature as the room, and see for yourself that the one with the warm water will not sweat. The temperature surrounding the pitcher containing the cold water is much warmer than the water itself. Thus the heated air in the room coming in contact with the colder surface of the pitcher, condenses, thus forming the drops seen on the outside of the pitcher. It is just so with your tobacco in the shed. In time of warm mucky weather, the air on the outside is much warmer than that $\mathrm{c} n$ the inside, and thus causes it to sweat, and there is not enough heat in the shed to cause evaporation fast enough to carry it off, and the result is your shed is filled with heavy damp air, that has been chilled by entering the shed and it condenses on the tobacco; and had you examined your crop at such a time you would have found it in the same condition as the pitcher of cold water in the warm room-not only wet on the outside, but so completely saturatedas to cause the rib of the leaves to bloat, or resemble a blister, and if it remains so for a few days it cannot help but rot. To those who may read these pages I would say: Do not condemn to hastily, but consider well; go and examine carefully for yourself, and if you do not find the crop in the same condition, it is not spoiling and it will be time enough to condemn my theory; for it is an established fact that which meets with no opposition is not worthy a sober thought. But you will doubtless say if that is the case our tobacco would all spoil and there is no remedy. Yes, I hold there is a remedy if taken in time in the 


\section{Proper Ventilation of your Building.}

To the person who contemplates growing Tobacco, the first thought that should present itself to his mind is, how or where will I cure my Tobacco, if I have it grown. You cannot give this point too much thought. If you wish to become a successful tobacco grower, you must be able to master difficulties as you meet them, and I can assure you that they will come. It is an old saying, that if all waters would run smooth there would be many more people drowned; and if the tobacco farmer would meet with no trouble on the way, it would be scarcely worth the raising. It requires a great deal of care and labor to grow and cure properly a crop of tobacco, and it is necessary to have a good place to cure it in.

Now my idea is this, that as two and two make four, so it is that pure and heated air rises from the surface and foul or damp air falls. Now for you to crowd large tobacco into a barn that has little or no ventilation at the roof, where do you suppose this air will get out when it does rise to the top, or what will be the consequence. I will tell you, it will fill your building full of fowl air, will smother and rot your tobacco. Now I will give you my opinion about a shed, backed up by experience and observation for many years. The closer you have a shed for curing the crop the better, and the day is not far distant when the grower will have his shed plastered or papered to cure it in and it will pay. I say this openly, without fear of being successfully contradicted. With an open shed you cannot keep damp air out nor heated air in. Now for an example : suppose you have a shed full of good tobacco, just on the turn to cure, or when some of the leaves are changing color, for that is the worst time, and we get three or four days or a week of wet, damp, mucky weather, and it gets among your tobacco, would you rather not have it out? I would, and I know you would, and would it not be good to have a place for the heated air to escape as it rises. I know you will agree with me again, but had you a reason for it before? My plan of ventilation is this, have an open (upola or one that can be opened at will extending the entire length of 
your shed up at the comb of the roof, so all air arising finds ready access to escape; down at the bottom of your shed have doors to open and shut and you are fixed. You can create a draft through your building just when you wish for that ventilation-works on the same principle as a chimney-if you should put up a chimney and place a stove pipe into it near the bottom and it will draw. Now go and make in your chimney a lot of holes between your pipe and the top and it will not draw. This shows the advantage over side ventilation, and for that reason I would recommend ventilation at the top and bottom only. The next question in the minds of the inexperienced farmer is,

\section{When is the Crop Ready to Strip.}

This is very important, for you cannot be too careful, for as you strip it so it will remain. To those who have not a cellar for dampening it is often a difficult matter. If you depend upon wet weather you should not onl examine the leaves but the stem of the leaves; take si or eight leaves together, tie them up properly, then tak the butts between the thumb and finger, and if the gr or hand hangs straight down, your crop is in good col, dition; but if the ribs break by tieing, or when taken stated, and the grip stands almost straight out you shouid not strip for you will ruin your Tobacco, as it will get rough and bony, and all the care you might bestow upon it will not remedy the evil, and the price of your Tobacco is lessened at least one-third, not alone in price but the quality, will be spoiled and great loss in weight. But if you have a cellar for the purpose this trouble is easily remedied; you have only to place it in the cellar and it will dampen just to suit. You can from a perfectly dry state make it too damp, and it requires you to watch it. Next comes the stripping.

\section{One Way to Strip Tobacco.}

This is very necessary to understand, for the way tmis is done greatly depends the price it will command. Fifteen years ago in Lancaster county among the most experienced growers when this branch of the business was 
to be performed, the grower would get all the boys and girls he could when a rainy day came, and this is the way the work was done. There was only two grades of Tobacco made, wrappers and fillers, and there was perhaps three or four of the ground leaves taken off and the balance was wrappers. 'The boys and girls received so much per pound, and then the race began to see who would receive the most money in the evening, or who could strip the most tobacco in a day. Regardless of quality it was tied up, whether long or short, dark or light, torn or whole, and in fact it mattered not what was the fault it might have had, it was wrappers at any rate, and the packer bought it at your disadvantage and to : his own benefit. 'The author has seen good crops of Tobacco bought in Lancaster county at from six to nine cents per pound. The grower of to-day would not conider himself very well paid for growing a crop at hat price now, and in fact would not for the reason that e puts much more labor upon it now than he did at tat day. Some of our rough, careless farmers, who ave never been paid for growing Tobacco, because they led to bestow labor enough upon it to have a marketle article, growed poorly and handled poorer. That - 3 ss of growers will likely say, yes but will it pay to torke all the pains and bestow all the labor upon the crops that some do. That question can best be answered by looking around and notice what class of men get the most money for their crops, and you will, I venture to say, find that those who bestow the most labor upon their crop, are the ones that have got the most money to put in the bank after their crop is sold. You may ask, but why did the packer sometimes pay a good price for some crops of tobacco in former times if it was poorly handled. I will tell you. During the time of our civil war in this country, the noted tobacco fields of Virginia and Kentucky were devastated by the marching armies, the emancipation of the slaves, (the bone and sinew of the Southern tobacco fields), was set at liberty with these disadvantages to overcome, in order to get back to the general routine of farming, was not only a matter of time, but a trouble that has not yet been fully overcome dur- 
ing this time, or prior to it. Lancaster county had obtained a smattering knowledge of tobacco farming, and the demand was on the increase while the production was on the decrease, thus it was that a new agricultural industry sprang up in our midst unthought of. The soil seemed to be well adapted to the growth of the weed, and to-day Lancaster county has acquired a reputation second to none, for its quality of tobacco.

So, kind reader, you can see that to supply the increasing demand, not only of home consumption but of a forgeign demand, devolved upon a comparative new field, and a people of little or no experience, could not be expected to cope with those localities where it had been grown and handled for years, and in fact can boast of its birth-place, and with those people who nursed it in its infancy and was able to hand their knowledge down to their children and their children's children. That is the great reason the packer paid some years ago a good price for poorly handled tobacco; the demand was here and the field was small, and he had little or no choice, neither had the manufacturer, thus it was, and he was compelled to buy it as it was; but let me inform you that these matters have changed, for the same reason that Lancaster county commenced to grow Tobacco. Not only other counties in this State, but many other States have commenced to grow the crop. The fields of twenty years ago have increased at least twenty fold, and I dare say fifty fold, for that reason the packer or the speculator in tobacco has a much larger field of labor and can afford to be much more choicey. We have drifted into this change by the march of improvements and the ambition of men, and we must be governed accordingly. We have not done it ourselves, as many say we have spoiled the packer -that is not so-he can be more particular about the quality of his tobacco, and I do not see any grounds to blame him. That is the reason that it is necessary for us to grow a good quality of tobacco and handle it with care. In order to give a better idea to the tobacco farmer who wishes to become successful; in other words to be well paid for his labor. I care not whether he has been growing it for twenty years; I would say it will not pay 
any one to farm poor tobacco. The whole world wants good tobacco and is willing to pay for it; while no one wants poor tobacco at any price, then it is far better to have one acre of good tobacco well handled, than three acres only half grown and poorly handled; perhaps you will say I do not know how to handle it well. I now propose to tell you, but in order to more fully impress it upon the minds of my readers, allow me to say, I wish to be plain and practical, that in Lancaster county, with the experience of thirty years, you will yet find some that will say, it won't pay to spend thirty days to strip fifteen or eighteen hundred pounds of tobacco. Allow me to give you the figures for it and count for yourself, and see if it will pay two neighbors side by side who are growing tobacco. They have both good ground and succeed in growing good tobacco, in fact so near alike that you can not discern any difference; and if you ask the opinion of good judges, they will say there is not one dollar difference. Now we will go to the cellar with those two men to see them strip and pack down tobacco for the inspection of the buyers. They both know equally well what is necessary to be done before it is safe to sell the crop by sample. They will both go at the work in good earnest, but soon the one will say, "this takes too long to suit me, I must get done to get to quarrying stone or something else that pays one dollar per day," and he hurries over it, and only does it about half and gets done in fifteen or eighteen days; but the other one sticks to it and goes along carefully, sorting it out and putting it up in good order, and he gets through in thirty days. Now it is ready for sale and the buyer comes. The one who stripped in fifteen days takes the buyer to see his tobacco and the buyer finds it pretty rough, piled up on two piles, and says-"wrappers and fillers, where is your seconds?" The farmer says I have none. The buyer thinks naturally they are among the wrappers, and there finds them. He pulls out of the rank six hands, and five out of the six are short-at least the shortest he has got and considerable of third grade tobacco. His questions are- "how much tobacco like this have you in this pile?" You may be strictly honest and say you really don't know, but don't 
think over two hundred pounds. And it may be true, but can you blame the buyer for disbelieving you when he pulled out five sixths of short out of the same rank; and the consequence is he buys your tobacco far below your expectation. Allow me to say at three and fourteen cents per pound, and you have eighteen hundred pounds of tobacco, not well handled, makes always one-third fillers. Now we will count: one-third of eighteen hundred is six hundred at three cents per pound or eighteen dollars, and the balance twelve hundred at fourteen cents per pound, or one hundred and sixty-eight dollars. The two together makes one hundred and eighty-six dollars. Now for the other side: The one who took thirty days to strip the same amount. The buyer comes to him to see his tobacco; he can with pride take him to the cellar, and says here is my tobacco-here pointing to the different ranks; here is so many pounds, thrible $A$, here so many double $A$, here so many pounds $A$, here so many pounds $B$, and here is my fillers. He will say I had not many seconds, and what I had I used up for tieing; but examine for yourself. He finds it so. The grower when asked, I want twenty-five and five for that crop. Pretty steep, he will say-but I will give you twenty-four and four for it-and he gets it. Now let us count well-growed and careful handled tobacco, does not make over one-fourth fillers. One-fourth of eighteen hundred is four hundred and fifty pounds, at four cents per pound makes eighteen dollars, and the balance, thirteen hundred and fifty pounds at twenty-four cents per pound makes three hundred and twenty-four dollars. The two together makes three hundred and forty-two dollars. Now the difference between one hundred and eightysix dollars, and three hundred and forty-two dollars is one hundred and fifty-six dollars, made in fifteen days or over ten dollars per day against one dollar made in the stone quarry. Is not this satisfactory? I think you can see at a glance what I am about to say is the same thing.

\section{The Proper Way to Strip Tobacco.}

When your tobacco is damp enough, but not before, take it down, strip it off the lath, a small quantity at a time; after that is done take off the ground leaves, say 
three or four, as necessary, lay down your stalk, take another and another, and so on; tie up your ground leaves as you go into hands of say ten or twelve leaves. After you have gone over it in this manner, take up the stalk again, look over and examine very carefully, and take out any torn or worm-eaten leaves, all you can find, and be sure you find them all. Look out for burnt leaves or leaves that has not cured well, or any thing that would not make good clean wrappers; those would be classed seconds, and are generally used for tieing up the entire crop, as they will answer the purpose just as well as a better grade. These should not be tied up, at least not all, but laid aside for tieing. Now you have disposed of the two first grades or fillers and seconds. Now what remains on the stalk is "wrappers, although not of the same grade. Now strip those off but do not tie up, but lay them on the table made for that purpose in grips as you take them off; do not, however, mix them up unnecessary, but make layers alternate, first one way and then the other, so as you can take them up again. This is a part of the work you can safely do by candle-light if you wish, this part and stripping off the lath can be safely done at night; but do not attempt to sort out the inferior leaves or lengths, and tie up without daylight and plenty of it, as tobacco cleaned and sorted by candle-light will not stand inspection by daylight; and it is very necessary you should have it well done, as a few leaves here and there through your crop may spoil the sale of it, much more than you may think; whenever you have doubts about a leaf put it in a lower grade. Thus any error may be on the safe side, when you have stripped off as many wrappers as you have room to stack on your table. Now go to lengthening off and tieing up into hands or grips; do not tie more than from six to eight leaves to a hand; not less than six nor more than eight leaves; have on your table vacant spaces enough to lay at least six different grips; take up your tobacco as you laid it down, place the butts even in your hand, then see how they correspond in length; do not tie leaves together in one hand, that there is more than an inch difference, and not that if you can avoid it by having spaces on your 
table; and you have a leaf longer than the rest lay it down, and when you get another of that length place it with it, and so on with each length. Make the butts even in your hand; select a leaf from your pile of seconds, about one foot in length to tie with. Commence with the butt of the leaf; wrap tightly about two inches, drop the end through the grip to fasten, roll it in your hand and the job is done; you must be very careful about the color; do not on any account put leaves in the same hand of a dif ferent color-as some is darker than others. As you tie up hands of different length keep them apart, make a pile in some convenient place, close to you, so as to drop each length separate. Now I cannot too strongly impress upon your mind this very important matter, for that reason I have endeavored to give you both sides of this question for you to consider, and I hope you will profit by it, for upon this greatly depends your success.

\section{How to Stack it up in the Cellar.}

This is very important, as you can put it up so as to bring you fifty dollars more or fifty less to every ton of tobacco. You must now prepare a place for to stack your crop. I will endeavor to give you a plan for that purpose; however you must be governed by the amount of tobacco you have got-the more, the more room you need. If you have three or four acres, I would suggest seven blocks, at least six inches thick; eight would be better, as that would keep it further from the earth, say torty inches long, place them in your cellar in such position as to be able to walk all around it; upon these blocks place a tight floor of boards at the one end, at least eighteen inches from the wall, set upright, two boards, fasten them above and below, so as to keep them to their places; six feet from them set up the same way two more, six feet from them; two more, and so on until you have six spaces of stalls. Now I propose to stack down on this platform the tobacco just as it is to go into the case. Thus tobacco 28 inches and upward in length, in the first stall, from 26 to 28 inches; in the second from 22 to 26 inches; in the third place, and from 22 to 18 inches in the fourth stall; all under I 8 in the fifths; the sixth for the seconds, and the 
last for the fillers. Now as you strip, pack down, as described; however, there is in this case as well all other matters pertaining to tobacco, a right way and a wrong way. Now I propose to direct you in the right way, thus: Place it upon the platform with the butts in opposite directions, but care must be taken not to get it too wide. You must be governed by the length of your tobacco; the longer your tobacco the wider the rick must be; you must let the points of the leaves lap over considerable, so as to keep it high in the middle; if you allow it to become low in the middle your rick may fall apart at any time; and if it stands for some time, as it often does, it runs into a sweat; and if your rick is too low in the middle, the heat draws there, and it may burn; at any rate it will cause your tobacco to get rough in the middle of your rick; and just here let me say to you, keep the butts of your tobacco even in ricking it up, as it will hold the moisture much better than if it is put up uneven. Now you will discover after your tobacco has been put down some time it will begin to heat; this you will be able to tell beyond a doubt when you go into your cellar. In the early morning you will find a very strong odor coming from your tobacco; and if you go, and down near the bottom of the rank raise the butts and place your hand in, you will find it getting warm. Now you must not under any circúmstances disturb it. This heating is only natural and it will not hurt; no matter how hot it gets, just let it alone, do not move it, and never put any weight upon it. In case it should commence to sweat before you are done stripping, do not even put any more on that rick, but make another rick; if you move it so as to let the air come in contact with it, your tobacco will get rough and bony, and you cannot change it, it will remain so. You should not by any means deliver it, if sold, while it is sweating; but inform your buyer of the fact, and he will, without a doubt, advise you, just as I have done; if he don't he does not know what is for his benefit, or care for yours; you will both be losers. Now I have advised you to put up your tobacco in different ricks in the cellar; in fact, the wrappers in five stacks. You perhaps will say, why are not wrappers all wrappers? Yes, 


\section{6}

certainly they are, but they are not all alike or else I would not have given you that advice. Now suppose you have your wrappers all on one rick, the long and the short, and the buyer comes to see your tobacco, he can, by a knowledge of his own, pull out of that rick all your short tobacco. Now he does not like to buy by random; no, he has some guide whereby he is governed and from which he makes his calculations. It is poor policy to sell by random. You should by all means be able to tell nearly how your tobacco runs, and by ricking it up as I have described, you can tell to a certainty just what you have got; the buyer will have no trouble to tell just what he can pay for it. Now cannot you see at a glance that my method is best for you, and best for the buyer; he has no need for supposition, he knows for a certainty what you have for sale. But on the other hand, if your tobacco is put up on one rick, the buyer is very apt to make his calculations so as to come out on the safe side himself; and he is not to blame for it. Now allow me to say, too, if you have carefully followed me from the selecting of your seed, through all the different processes necessary, you have an article to-day to offer to the buyer you have no reason to be ashamed of, and you will have no trouble to dispose of it at its full market value. That will be satisfactory to yourself and to your buyer, and you need not feel ashamed to deliver it at the appointed time and place, and will meet with no difficulty by so doing.

\section{Getting Ready to Deliver. your Crop.}

This is another branch of the business which should be understood, as it is very necessary to be able to deliver it in good order; first you want a bailing box; I will describe a cheap one that you can make yourself, and it will give good satisfaction, it is made thus: Take a piece of pine plank, two inches thick and three feet nine inches long, sixteen inches wide upon the underside of this spike. Three pieces across the plank, one in the middle, the other ones four inches from either end, this is for the bottom. The rough should be planed off the inside of all the pieces, for the back a one and-a-half inch plank, 
three feet three inches long, eighteen inches broad, this sets upon the edge of the bottom plank; one-inch boards of the same width, and sixteen inches long for the ends; nail the back down to the bottom plank, with the front towards you, the left hand end you nail against the back and down to the bottom; the right hand end should be fastened to the back with a pair of strap hinges, so as to open outward. Now you have the bottom, the back and the two ends; what you now want is the front, which is made out of inch boards, and must be twenty inches wide by three feet nine inches long; it can be made of two pieces, as it is necessary to have ledges on the outside and light ledges on the other side, outside of the ends, so as to keep it in its proper place. This is fastened to the outside against the bottom, by three strap hinges so as to drop down at will; to keep it to place, when shut, have spring hooks fastened on the top edge of the ends, so when you raise the front they will fasten themselves and hold it to its place; you will now find you have a box three feet three inches long, fourteen and a half inches wide and eighteen inches high; now have a good solid lid with ledges on to fit the box for pressing your tobacco. To do the pressing, place your box near a good post in the cellar in which you bore a number of holes to suit; with a crowbar, or something of the kind, a good stout stick, about six feet long, with a ring on the end, and an iron pin in the end answers the purpose. Now you have a box that is easily made and will not cost over two dollars, and will answer the purpose as well as a patent box costing twenty dollars, and is just as handy. Now you have a description of a box for bailing; now how to bale the crop is next in order. Now I propose to tie up in paper, it will make money for you and money for the packer. Paper enough for a bale as large as my box, and no bale should exceed seventy-five pounds, will cost you about six cents; this, and more than this, you will lose in weight; but this is not the case, for if the packer knows what is for his benefit he will insist upon you tieing in paper, and you get the same price for your paper as for your tobacco. Now how will it pay the packer in this way? The tobacco will dry out by being more or less 
exposed to the air, especially if sweated, and there are several thousand leaves exposed to the outside of a bale. Now in handling it, no matter how careful, there is any amount of them broken by being too dry, and by taking hold you cannot help tearing some with your fingers, and in other ways are broken and damaged, get light paper for the purpose, and just put enough on to reach around, tie carefully, and all this trouble and damage is avoided, and your tobacco goes to the packer in a condition you can be proud of, and he has gained considerable, and you are paid for your extra labor and expense; and you are both highiy pleased and both have confidence in each other.

\section{How to Bale your Tobacco.}

First, you want twine to tie with; this you can secure at any country store; cut into length to reach around your bale; three for each bale; place them in the box, one in the middle, the other two about five inches from the ends, fasten in that position; next place your roll of paper in front of your box, unroll enough to reach down and across your box, with the end bent over the upper edge of the back of your box, press down into the box and place in your tobacco, commencing with your first stall; fill in with the butts towards the ends very carefully, so as not to have the leaves doubied up; fill up, rounding full, put on your lid, place a block on top; now get your lever, press down tight as possible, let it remain a bit, cut off your paper on the edge of your front, take off your lid quick, double over your paper, place your knee upon it to keep it there and tie it, raise your springs, let your front drop down, open out the end on hinges, and there lays your bale as if it was in the corner of a room, proceed thus until you are through with that grade, label them what they are and proceed with the next grade in the same way; it is not, however, necessary to tie up the fillers in papers; just tie with twine, without paper; but do not in any case disturb it while it is sweating, or you will ruin it; and I am safe in saying that any packer will tell you the same. It has been said by some growers that the packer would not allow them to tie in paper. I question 
the truth of that assertion, as I think I have made it plain to every intelligent man that it is a saving to both buyer and seller. There is often considerable trouble between buyer and seller when the tobacco is delivered. Now there is certainly some cause for this, as I have never seen any trouble arise from nothing. There is no doubt unprincipled buyers, and I know there is unprincipled "sellers. This I know, for I have seen this for myself. I cannot say anything against the buyer; for myself I have never had any trouble, they bought my tobacco when it was not stripped, and I stripped it just as I have described it to you here; and when I delivered it the buyer was more than pleased; but on the other hand, I have heard it said my tobacco is sold, and I don't care. I am not going to put very much work upon it; others I have seen put water upon it and stalks tied up in the bales. Beef heads and stones I have heard of, and the like, and I have been always of the opinion that where there is no reason for trouble there can be none. There may perhaps be among tobacco buyers as among all other classes of men, some one who would take the advantage, yet.when I look around me I wonder to myself that there is not more docking done than there is. I have seldom seen a man docked who wishes his neighbor as himself, for my part I have no fear of being docked when I deliver my tobacco. I have always prided myself in delivering tobacco that needs no docking; and I think if my brother farmers would but follow my advice given in this work, they will sell their tobacco for more money, and get, when delivered for it just what they sold it for, and have the confidence of the buyers. 


\section{A REVIEW.}

Now, kind reader, in conclusion allow me to congratulate you on having raised a good crop of tobacco, handled it well all through, and at last obtained a good price, which you are entitled to, and have gained and held the confidence of the buyer who bought your crop, and last but not least, have gained a reputation as a good and careful tobacco farmer, which you can hold by strictly following the advice so plainly laid down in this work; the principal points to be attended to if the best results are to be obtained may be stated in a few paragraphs. These paragraphs embody principles and prescribe modes of management nearly identical with those to be considered in the treatment of other crops :

Ist. Give it your personal and careful attention in all its branches, and do not stand aloft, but see for yourself, and not through the medium of others; handle with your own hands and know of a surety that your crop is managed right.

2 d. Select good land for the crop, plough in autumn to get the multiplied benefits of winter freezes. This cannot be too strongly urged.

3 d. Have early and vigorous plants and plenty of them; it were better to have one hundred thousand too many than ten thousand too few. They are the corner-stone of the building. To make sure of them give personal attention to the selection and improvement of the seed; the preparation of the plant bed, and the care of the young plants in the means necessary to hasten their growth and protect them from all dangers as they may arise.

4th. In the preparation of and proper manuring of the soil, I would say collect manure in season and out of season, and from every available source; from the fence corner and ditch, bank the ash pile, distribute it with a liberal hand, nothing short of princely liberality will answer; plow plenty under, both the home-made and the commercial early, that it may become thoroughly incor- 
porated in the soil, and be ready to answer to the first and every call of the growing plant. Often (we believe generally) the greater part of manure applied to tobacco land. This is true of the bought fertilizer as well as that made on the farm, is lost to that crop by being applied too late. Do not fear it will all escape into the air before the plant needs it. This is an exploded fallacy; experience, our best teacher, has proven it to the contrary.

5 th. Seek to have a forward crop, as the benefits claimed for a late one from the fall dews to make more weight, do not compensate for the many advantages resulting from early maturity.

6 th. Keep the grass and weeds down, and the soil loose and mellow, by frequent stirring; avoid as much as possible cutting and tearing the roots of the plants in all stages of its growth, and more especially after 'topping. In the improvements in farm implements it is oftener practicable than is generally supposed. Substitute for handwork in cultivation that of the horse. The difference in cost will tell in the balance sheet at the close of the operation.

7 th. Attend closely to worming, for on it hinges in no little degree the quantity and quality of tobacco you will have for sale. A worm-eaten crop brings no money.

8 th. Topping is a very important part of this great work and requires knowledge and sound judgment, with a careful hand. See to it that the suckers are promptly removed. It is work quickly done, and with worming may constitute a single operation, and they are both very essential, the merest tyro knows to the full and perfect development of the plant.

9th. We come now to consider the last operation in the field. Cutting the crop in this, as in topping, sound judgment is needed. The farmer should never allow a careless or indifferent hand to perform this part of the labor; be there yourself, brother farmer; see for yourself how it is done. No one will see the interest in it you will.

I oth. I have so fully described the manner of stripping on preceding pages, it is hardly necessary to give but a passing notice here. Be sure, however, to keep a careful watch over it and see that the long go with the long, and 
the short with the short; the light in color in one hand and the dark in another; and have it properly classed.

We sum up the whole by saying, do not grow too large an acreage; but let your aim be to grow as much on one acre as you do on two-at least aim at twenty-five hundred pounds to the acre. By growing good tobacco you will always find a ready sale fur it; but attempt to grow two acres more than you can properly manure and handle, and you make a miss with your entire crop. This has been the trouble in our county for the past ten years. Our farmers are getting too ambitious, and do not consider that it is not the number of acres, but the amount to the acre that pays the largest percentage. Allow me to close by saying, that it has been my object to guide you carefully on from the seed to the packer, trying to help you over the difficulties attendiug the growing crop. By heeding my advice given, you will be able to stand on ten years experience, as safely secured against loss as your neighbor. What you may gain by carefully reading this book has taken the author many years of close study and many fruitless experiments, but has succumbed to none, and to-day stands with as good a record of sales made in the past as any in the county. I give it to you as my actual experience, and would ask you to read it carefully; consider it well and criticise it accordingly. If by reading this book you have gained what is necessary to become successful in growing the crop, you must not only read it carefully but be guided by it, and I feel sure this little book will meet with a ready welcome before this year is out May you receive it in the same spirit it is given. If you do so the ambition of the author is complete.

\section{The Plan for a Good Shed.}

The author of this work claims to be the first one to introduce the improved shed, with stationary board scaffold and open from floor to roof, with ventillation only at the bottom, and comb of roof. In fact the plan is original with him. For the benefit of the patrons of this work who may wish to build a shed, he gives the plan or at least an outline of it. Here it is : Let us suppose a 
size for a shed, say sixty feet long by thirty-two feet wide. Before I am done I will give you my reason for this size or any other. Now in the first place have a good cellar dug out, against a hill, facing the south, if possible; have an eye to your own interest, and do not place it too close to your other buildings, in case you wish to have your shed insured, when full, as you could not get its value full of tobacco insured, in case it stood too close to your other buildings. Now get a good wall put up, at least eight feet high; on the south side have a door and four windows, have two heavy girders running lengthway and the joice from wall to wall; now we want a driveway through the middle, twelve feet wide, made, if possible, to drive in at one end and out at the other; this must be laid with jointed plank or double with inch boards, ten feet on each side with flooring, so as to have a perfectly tight floor; now we have the bottom of the building, we propose to have twenty-one feet to the square; then place two main posts, one on each side of the driveway, and start at the corner with a main post, and every forty-five inches another stud, though not so heavy, and so on until you get to the other corner, and you will find you will just hold out; however, you should have three main posts on each side fifteen feet apart, to receive the span plates on top, and the braces from the floor, the other end fix with two more main posts at the driveway, and by starting again from the corner, make just as the other side with three main posts and a light one at every forty-five inches; now brace from the floor to within one foot of the top of the corner posts, and seven and a half feet out at the bottom; now you want two more studs in each end, between the corner posts and the driveway posts, and a brace at each one of those mainposts in the sides, from the floor to within one foot of the top; now you want five spans over the top, morticed on top of those heavy posts and your rafter plates, and your skeleton in complete. Now you want two light stringers, the lengthwise of the building on top of the spans from the top of the driveway posts, one on each side to receive and keep in place your inside studs, which is set in line with the two main driveway posts, just forty-five inches apart; now leave your driveway twelve 
feet high so as to answer any emergency; now the scaffold is just six inch board, running the crossway of the building, starting at the span, which answers for one; now the first four from the top down, have four feet four inches apart, which will let three feet eight inches for the short tobacco, which is always last coming in; use nothing but long braces; now have it boarded up with worked boards so as to be perfectly tight; let at the bottom next to the plate, a door at least two feet wide to hang on hinges to open ('r shut at will, and a cupola extending the entire length of the roof, with doors; this is all the ventilation you want, and the only ventilation you should use; thus, with this ventilation at your hand you can close your shed in time of damp foggy weather, thereby preventing your tobaccu from pole-rot, which is very common where damp air cannot be kept out. Now have your cellar well plastered so as to have it tight, and have a room cut off at least eight feet wide on the south side, the entire length of your building, with a close partition for a stripping ruom, have on a level with the bottom of your windows, a table made the lengthway for stripping and sorting; have it made strong and out of surfaced boards; you want about three trap doors in the floor so as to get your tobacco from the building to the celiar for dampening; perhaps you may not need so large a shed; if not, just start at asiven point and measure forty-five inches; make a mark then; measure furty-five inches again and you can stop at the end of any number of measurements $y c u$ wish, and you have no vacant room. This is the reason why I proposed a shed sixty feet long, as you can see at a glance that this just comes out even, so will thirty or ninety or a hundred and twenty feet. I have given you a faint outline of the best shed now in use; yuu cannot, however, get an idea of the advantages of a good c nvenient shed with dampening cellar and stripping room until you have one yourself. 


\section{CONTENTS.}

The Selecting and Management of the Seed Stalk . . 5 The Selection of the Seed Bed . . . . . . . 7

The Preparation of the Seed Bed . . . . . 8

How to Sprout the Seed . . . . . . . . . . 9

The Proper Time for Sowing Seed . . . . . . Io

How to Sow the Seed......... Io

Management of Plants........... II

Huw to Prepare the Ground for Transplanting . . I 2

The Time for Planting. . . . . . . . I4

How to Plant Tobacco . . . . . . . . I5

Cultivating the Tobacco. . . . . . . . I9

The Tobacco Worm........... 20

The Process of Topping . . . . . . . . . . $2 \mathrm{I}$

Suckering the Tobacco . . . . . . . . . 22

How to Cut the Tobacco......... 23

How to Hang the Crop in the Shed . . . . . 25

Proper Ventilation of your Building . . . . . 27

When is the Crop Ready to Strip . . . . . . 28

One Way to Strip Tobacco........ . 28

The Proper Way to Strip Tobacco . . . . . . 32

How to Rick it up in the Cellar . . . . . . . 34

Getting Ready to Deliver Your Crop . . . . . 36

How to Bale Your Tobacco . . . . . . . $3^{8}$

A Review .. . . . . . . . . . . 39

The Plan for a Good Shed . . . . . . . . $4^{2}$ 

-

$$
\text { - }
$$



00222656059 